\title{
Hydrochemical study of the Caldas Novas Thermal Complex (GO), Brazil
}

\author{
Marina Lunardi ${ }^{1} \mathbb{D} \cdot$ Daniel Marcos Bonotto $^{1}$
}

Received: 3 November 2016 / Accepted: 6 January 2018 / Published online: 24 January 2018

c) Springer-Verlag GmbH Germany, part of Springer Nature 2018

\begin{abstract}
The city of Caldas Novas, State of Goiás, Brazil, holds the largest thermal water complex in the planet not associated to with volcanism or other kinds of magmatism. Its structural control allows the fractures to be wide and deep enough so the waters can reach $1000 \mathrm{~m}$ depth. These waters are extracted mainly by deep wells, from the exploitation of the Paranoá and Araxá Aquifer Systems, emerging at temperatures higher than $59^{\circ} \mathrm{C}$. With a growing demand for water resources, groundwater exploration became an attractive alternative for public supply, due to its abundance, quality and low abstraction cost. In Caldas Novas, due to the population growth over the last decades and the increasing number of tourists, a disordered groundwater consumption drawdown the water levels. In order to survive, these reservoirs depend on rainwater infiltration rates to replenish the thermal springs; however, the lack of environmental management and the high risk of contamination, due to the unconsolidated materials thinness, may threaten the thermal aquifer. This study was based on the hydrochemical characterization of Caldas Novas Thermal Complex waters, including radioactive parameters, whose descriptions in the literature are still scarce. Besides, concerning the prospective increase on touristic activities, physicochemical water analyses are periodically required, being this paper a contribution for such purpose.
\end{abstract}

Keywords Thermal aquifer $\cdot$ Hydrochemistry $\cdot$ Radon $\cdot$ Uranium $\cdot$ Caldas Novas

\section{Introduction}

Water is one of the most important natural resources for life maintenance, and it is renewable by atmosphere, biosphere, hydrosphere and lithosphere relations. Unfortunately, anthropic actions are threatening water renewal rates through harmful land use processes and indiscriminate natural resources usage (Almeida 2011). The current amount of Earth's water is considered to be stable for 500 million years; however, $97 \%$ of this water can be found in the oceans and, therefore, is salty. Apart from the percentage frozen up in glaciers and ice caps, barely $0.6 \%$ of all water on Earth is fresh, and the majority of this tiny fraction can be found underground in aquifers (CETESB 2016). The Caldas Novas Thermal Complex, located in southern Goiás State, CentralWest region of Brazil, is one of the largest occurrences of

Marina Lunardi

marina.lunardi@gmail.com

1 Instituto de Geociências e Ciências Exatas, IGCE, Universidade Estadual Paulista, UNESP, Av. 24-A, No 1515, P.O. Box 178, Rio Claro, São Paulo CEP 13506-900, Brazil hot groundwater without association with volcanism or other magmatism phenomenon (Costa et al. 2013). These waters contain low mineral levels and for that reason are classified as oligominerals. Its poor mineral content is directly related to rock composition types on that area, such as quartzites and schists. Despite the low saline contents, those waters have proven therapeutic benefits related to its warmth and gas emanation (Teixeira et al. 1986).

Due to a growing demand for hydric resources, groundwater exploration became an attractive alternative to public supply for its abundance, quality and low abstraction cost, especially considering the inadequate conditions of surface waters and its high treatment costs. Thus, groundwater is progressively becoming a disputed resource, considered by many as a strategical source for socioeconomic development and which must be protected (CETESB 2016).

Caldas Novas is a city that has grown based on hydrothermal tourism. Its thermal springs are solely replenished by rain precipitation, which, along the years, suffered a drastic drawdown on water levels, attributed to an increase in pumping rates, land occupation and surface sealing, limiting the natural recharge of aquifer systems (Almeida 2011). There is 
also a great concern about water contamination risks on this area, mainly due to the thinness of unconsolidated materials, associated with a sunken terrain and a low depth static level.

The Araxá Aquifer water level suffered a gradual and continuous decline, due to unbridled pumping rates, until it reached $617 \mathrm{~m}$ in 1996 (Fig. 1). Back on those days, the entire population was provided with drinking water from thermal wells. Shortly after, the water supplies coming from thermal wells were replaced by a water catchment system from Pirapitinga stream. Also, a greater control on thermal wells pumping rates for mining companies has been established. These measures have contributed to a significant increase on Araxá Aquifer water level, rising from $617 \mathrm{~m}$ on January 1996 to 653 m on April 1998 (36 m elevation).

Caldas Novas and Rio Quente thermal waters are used following a legal regime of authorizations and concessions governed by Brazilian Mining Code. Since 1996, the granting of new thermal water research permits for balneotherapy was suspended on those municipalities. Currently, 84 mining processes are regularized or in regularization progress at the National Department of Mineral Production (DNPM).

Exploitation flows authorized by DNPM vary from well to well. Of current wells in operation, the lowest authorized flow rate is $6.0 \mathrm{~m}^{3} / \mathrm{h}$ and the highest authorized flow rate is $35 \mathrm{~m}^{3} / \mathrm{h}$. The total flow sum authorized for these 84 operating wells results in $1.800 \mathrm{~m}^{3} / \mathrm{h}$, which corresponds to an average flow of $20.2 \mathrm{~m}^{3} / \mathrm{h}$ per well and an authorized volume of $9198.000 \mathrm{~m}^{3} /$ year. According to Peixoto Filho (2000), these flow rate approvals are based on a pumping policy which determines $14 \mathrm{~h} /$ day for pumping and $10 \mathrm{~h} /$ day for recovery. The depth of most wells varies between 300 and $650 \mathrm{~m}$, yet some wells have depths greater than $1000 \mathrm{~m}$.

It is known that, over the years, some springs may suffer chemical alterations. Most chemical analysis of Caldas Novas waters were made in late 1980s and, due to a progressive increase in touristic activities, there is a constant need for periodical chemical surveys. Furthermore, lack of radioactivity data about those springs calls for new researches on this field, being this study a contribution to fill some of these gaps.

\section{Area of investigation}

The studied area is situated in the Central-West region of Brazil, southern Goiás State, distant $350 \mathrm{~km}$ from the federal capital, Brasília. Caldas Novas Thermal Complex area

Araxá Thermal Aquifer water level obtained with altimetry (starting June/1979) Paranoá Aquifer piezometric levels (starting September/1996)
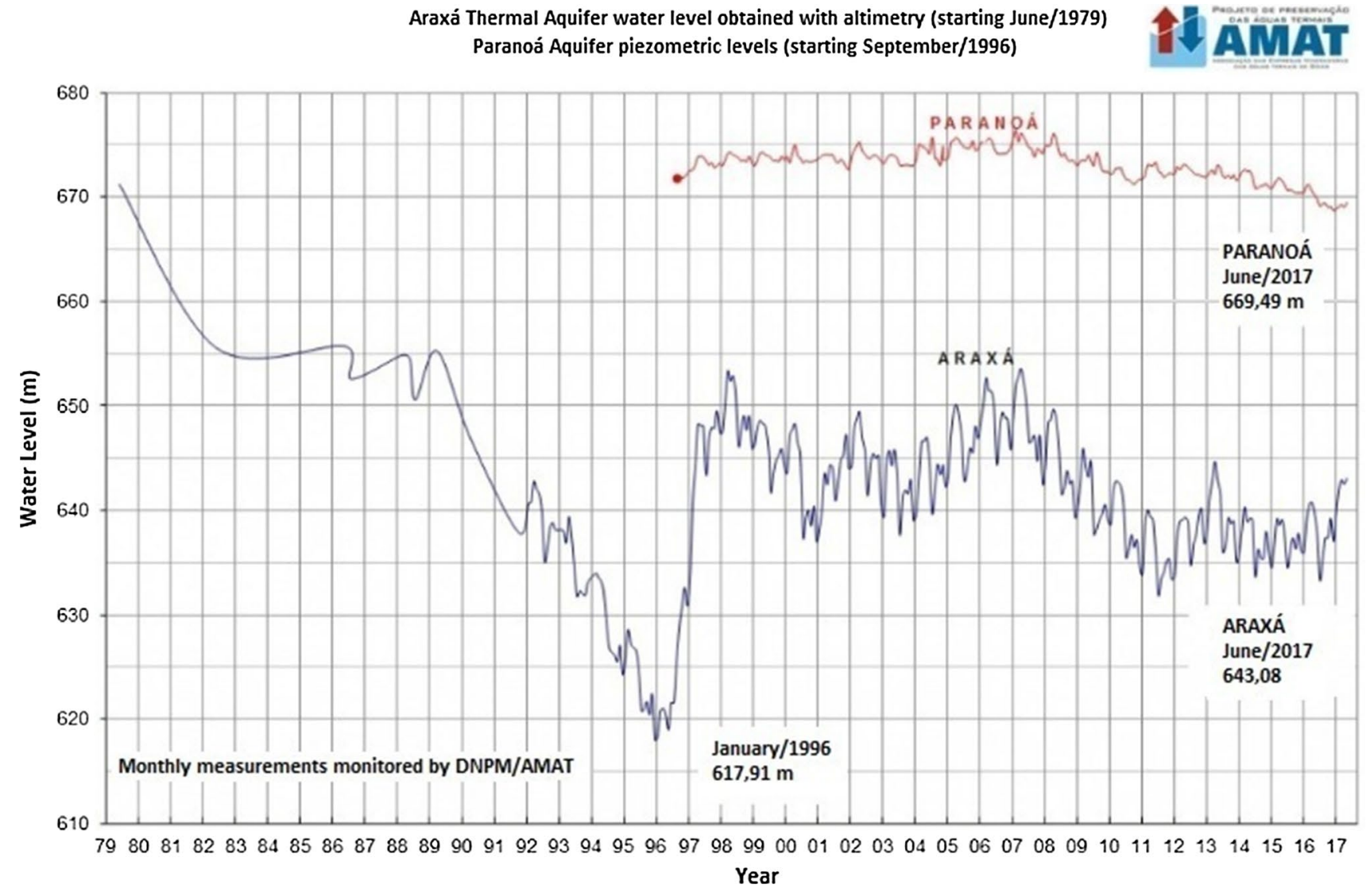

Fig. 1 Groundwater level variation of Araxá Aquifer System and piezometric levels of Paranoá Aquifer System. Adapted from amatgo.org.br 
includes both Caldas Novas and Rio Quente cities, and the Pirapitinga Lake as well. This complex is a part of the internal zone of the Neoproterozoic Brasília Belt, comprising rocks from the Paranoá, Araxá and Areado Groups (Andrade and Almeida 2012). It forms, along with the Araguaia and Paraguay belts, a Neoproterozoic geotectonic unit known as the Tocantins Province (Silva et al. 2008). According to the authors, this province is bounded by Parnaíba and Paraná Phanerozoic sedimentary basins, and it results from the paleocontinents precursors of the collisions of Amazonian and São Francisco cratons, as recorded by polydeformed and metamorphosed Archean Neoproterozoic rocks. Its geology is characterized by a tectonic superposition of rocks from Paranoá Group by the rocks of Araxá Group, forming a nappe feature (Figs. 2 and 3). The combination of fractures and regional antiforms is the main responsible for heating the groundwater.

The Paranoá Group is a sequence of psammitic-pelitic sediments of low-grade metamorphism (Andrade and Almeida 2012). This group was divided by Campos et al.
(2009) in four lithostratigraphic units, from base to top, as orthoquartzites, argillaceous quartzites, metarhythmites and pelitic-carbonates. These rocks are associated with the Paranoá Aquifer System, which contains the highest temperatures of Caldas Novas Thermal Complex.

The Areado Group covers the rocks of Paranoá Group on the top, eastern and western edges of Caldas Novas Dome (also known as Serra de Caldas Plateau), an elliptical structure with a NNW-trending axis as long as $20 \mathrm{~km}$ and minor axis of $10 \mathrm{~km}$. Those rocks consist of a laterite cover with a sandy nature and reddish color that occurs associated with conglomerates (Haesbaert and Costa 2000).

The Araxá Group consists of greenschist-amphibolite facies mica schist rocks which recovers Paranoá Group sediments, composing a nappe form (Campos et al. 2009). These rocks correspond to the flat terrains on the surroundings of Caldas Novas Dome and are related to the Araxá Aquifer System, the most exploited aquifer of Caldas Novas Thermal Complex.

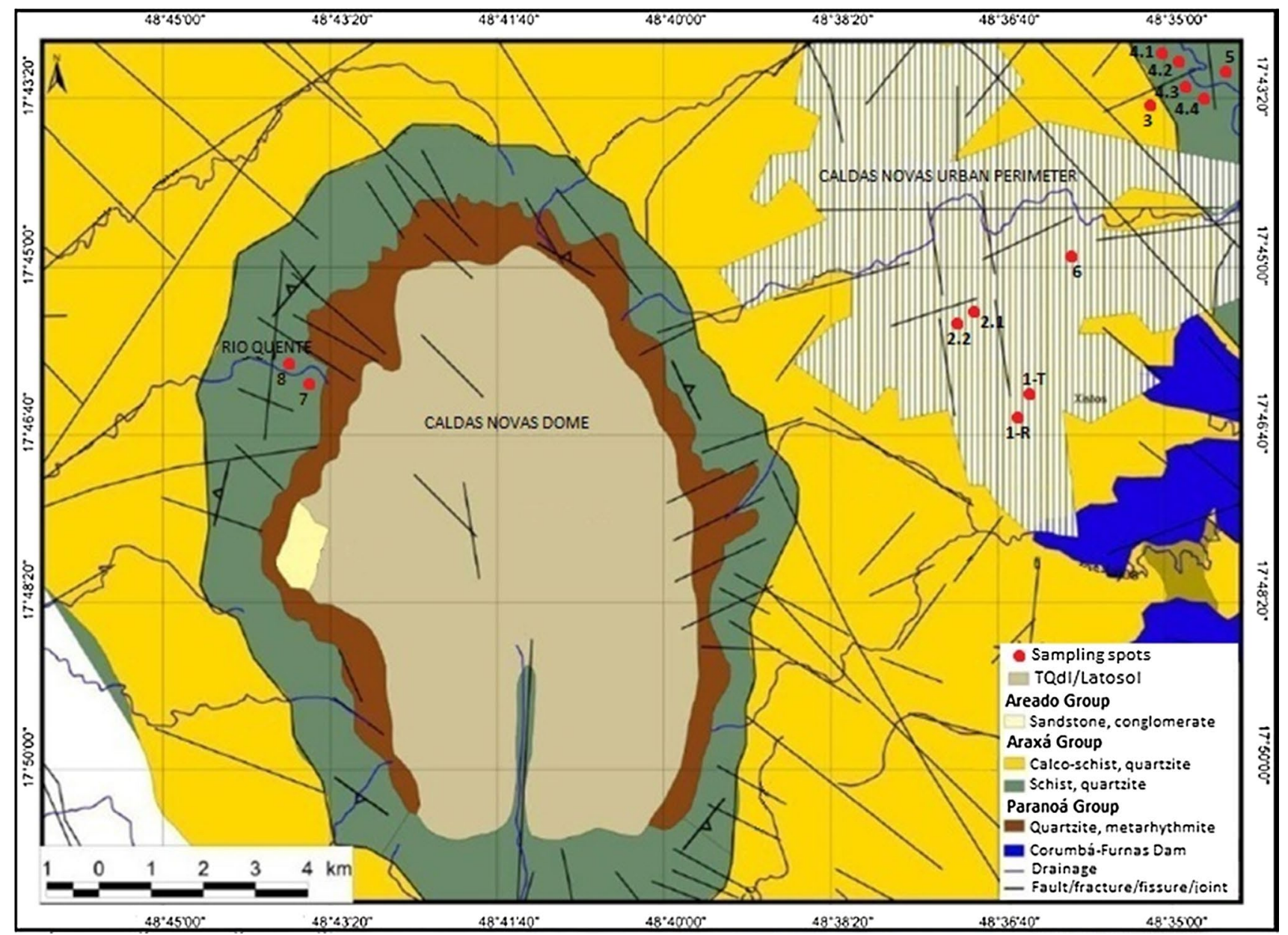

Fig. 2 Sketch map of study area with specified samples and their locations. Reproduce with permission from Almeida (2011) 


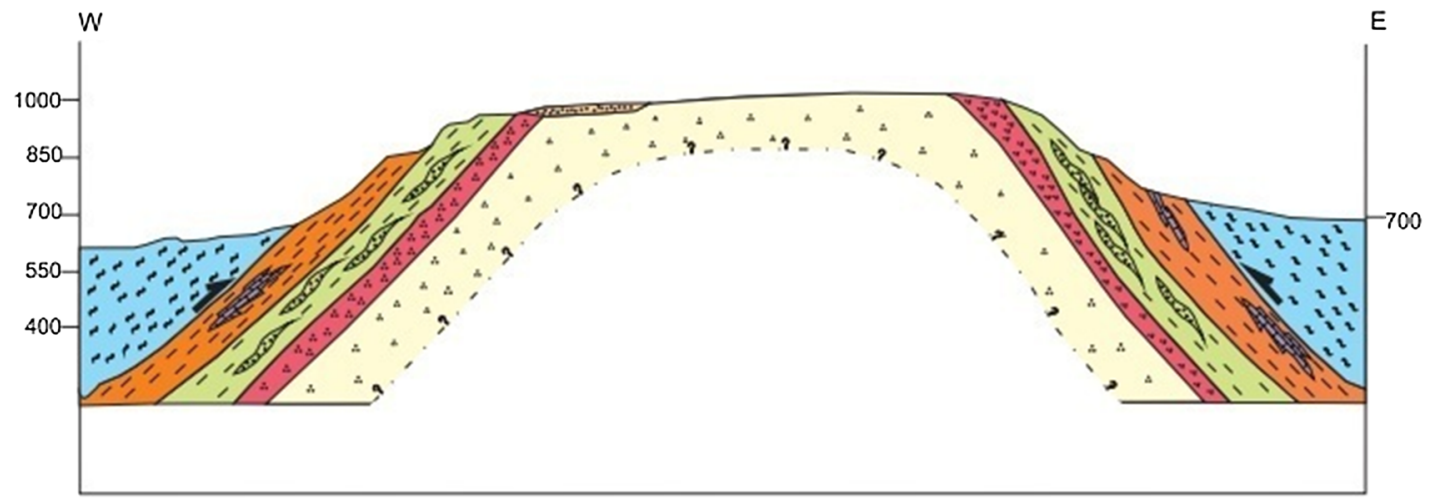

\section{Areado Group - Early Cretaceous}

Conglomerates, sandstones, argillites and shales
Paranoá Group - Middle/Late Proterozoic
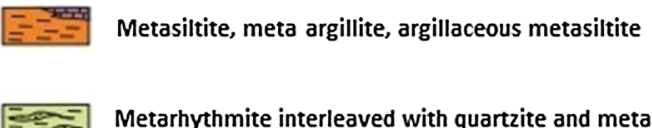

Metarhythmite interleaved with quartzite and metasiltite

Quartzite: argillaceous, laminated, immature, brownish-red colour

Orthoquartzite: silicified, wave ripples, crossed stratification, white colour

Fig. 3 Schematic geological map representing an east-west section in the central portion of Serra de Caldas. Reproduce with permission from Campos et al. (2009)

\section{Hydrogeology}

Caldas Novas Thermal Complex is widely known for being one of the largest hot springs occurrences in the planet not associated with volcanism or other kinds of magmatism. The terrain structural control allows the fractures to be wide and deep enough so waters can reach over $1000 \mathrm{~m}$ depth, and warming due to geothermal heat. When heated, those waters migrate to surface through fracture systems, forming thermal springs.

Previous hydrochemical studies performed by Campos et al. (1980) have shown that the lack of boron, arsenic, cesium and rubidium suggests an absence of hydrothermal processes originated from igneous fluids. Also, according to the authors, magnetometers sensors have demonstrated an absence of basic/ultrabasic igneous rocks under the Caldas Novas Dome.

There are three aquifer groups in Caldas Novas Thermal Complex that differ on chemical characteristics, circulation patterns, temperatures and rock types (Fig. 4). These aquifers, divided into Intergranular Aquifer System, Paranoá Aquifer System and Araxá Aquifer System (Fig. 5), are interdependent and associate themselves in local and regional hydrogeological flow (Campos and Almeida 2012).

The Intergranular Aquifer System is characterized by its cold waters (below $25^{\circ} \mathrm{C}$ ) and low mineralization, because the contact between rainwater and rock/soil is so fast, resulting in low concentration of dissolved elements. This system comprises a set of free aquifers with lateral continuity, large extent and very variable thickness (Campos et al. 2009).

The Paranoá Aquifer System has an estimated water reserve of $180 \times 10^{6} \mathrm{~m}^{3}$ (Campos and Almeida 2012) and consists of fractured aquifers, free or confined, cold or hot, anisotropic, heterogeneous and with lateral extent controlled by major lineaments (Campos et al. 2009). It is classified as free when the fracture zones are associated with peliticcarbonate rocks of Paranoá Group and confined when the fracture zones are covered with schist from the Araxá Group. These waters are considered to be cold when descendant flows reach depths smaller than $400 \mathrm{~m}$ (situation usually associated with aquifer portions classified as free aquifers) and hot when descendant flows reach depths greater than $450 \mathrm{~m}$. According to Haesbaert and Costa (2000), water temperature that comes off from the wells of this system may vary between 50 and $58{ }^{\circ} \mathrm{C}$, and its recharge occurs mainly from the infiltration of the flat plateau region of Caldas Novas Dome, through the drainage of Intergranular Aquifers System.

The Araxá Aquifer System has an estimated water reserve of $45 \times 10^{6} \mathrm{~m}^{3}$ (Campos and Almeida 2012) and corresponds to a very heterogeneous fractured system, anisotropic, free, cold or hot. It has a restricted lateral extension and is controlled by fracturing zones, with depths ranging from 100 


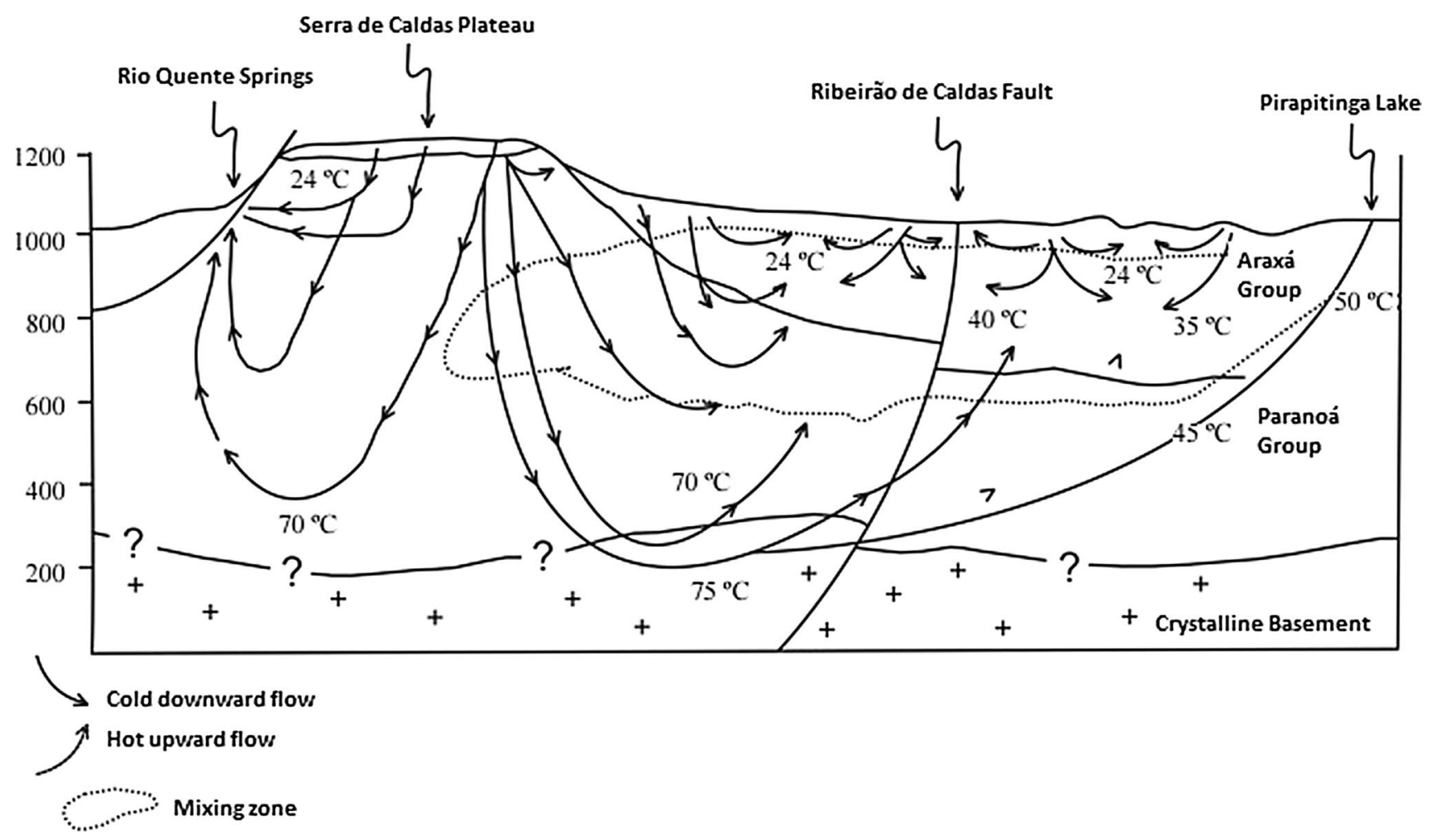

Fig. 4 Water temperature dynamic figure showing temperature variations and potential heat exchanges between different aquifers. Reproduce with permission from Campos and Almeida (2012)

Fig. 5 Schematic illustration showing the distribution of geothermal aquifers from a satellite picture

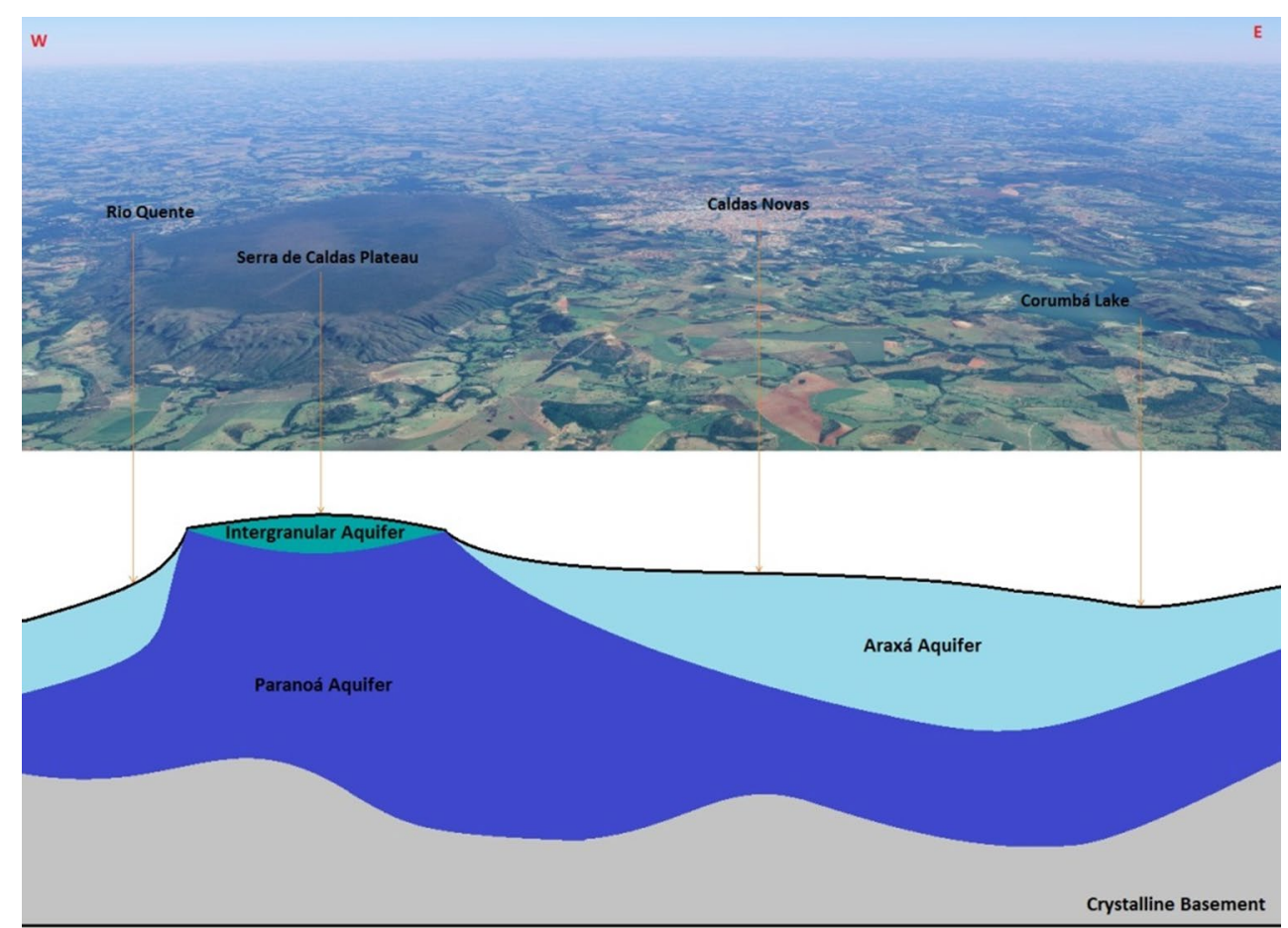

to $400 \mathrm{~m}$. Its waters are calcic-magnesian-bicarbonated and are the most mineralized waters in this complex, due to the high reactivity of shales, which have large concentrations of phyllosilicates, and to the constant presence of carbonates in metamorphic segregation zones (Campos et al. 2009). Aquifers from this system are considered as cold when its 
location corresponds to the first few hundred meters from shales column of the Araxá Group and considered as hot when located near deep fracture zones, close to the tectonic contact between Araxá and Paranoá groups. This system recharging takes place by upward flow from hot waters of the Paranoá thermal aquifer underneath. According to Almeida (2011), water temperatures of this aquifer range between 35 and $49^{\circ} \mathrm{C}$.

Almeida (2011) created a large scale map (Fig. 6) showing greater details on geothermal gradient contour with data obtained from wells in Caldas Novas urban perimeter. This kind of map is often hard to confect at this particular area due to a substantial anisotropy from aquifers, intense pumping of the wells and water mixing zones between Intergranular, Araxá and Paranoá aquifers. However, hydrogeological knowledge allows us to assume that Serra de Caldas plateau is the main recharge area (Fig. 7) and that there is a regional flow division characterized by the Rio Quente hot springs west of the plateau and thermal occurrences along a SW-NE trend (Serra de Caldas Plateau-Central Caldas Novas-Pirapitinga Lake).

Another geothermal gradient contour map (Fig. 8) was created by Ferreira (2003) but this time using a much larger scale that comprises the entire Goiás State. This map shows that geothermal flow ranges from 40 to $100 \mathrm{~mW} / \mathrm{m}^{2}$ in most parts of the state. The highest values, ranging from 200 to $300 \mathrm{~mW} / \mathrm{m}^{2}$, occur in southeast of Goiás State, coinciding with the Caldas Novas Thermal Complex area.

\section{Experimental}

\section{Physicochemical parameters}

At the field, the samples were collected and stored in polyethylene bottles and some physicochemical parameters were immediately performed, because its properties might change during transportation to the laboratory, such as temperature, $\mathrm{pH}$, Eh, conductivity, dissolved oxygen, dissolved hydrogen sulfide and dissolved carbon dioxide.

Protonic and electronic activity determinations $(\mathrm{pH}$ and Eh) were made with portable Digimed device. The $\mathrm{pH}$ measurement was taken by a digital portable meter coupled to a combination glass electrode; buffer solutions equilibrated with the sample temperature were utilized to calibrate the equipment before the analyses The Eh measurement was realized with the same $\mathrm{pH}$ digital portable meter after disconnecting the $\mathrm{pH}$ electrode, selecting the " $\mathrm{mV}$ " position, and connecting a combination platinum electrode $-\mathrm{Ag} / \mathrm{AgCl}$ reference element. Such electrode have to be previously calibrated using a prepared Zobell I reference solution (Zobell 1946) and adding the measured cell potential to the potential of the $\mathrm{Ag} / \mathrm{AgCl}$ reference electrode at the measurement temperature. According to Bonotto (2012), the difference between the measured Eh and actual Eh of reference solution has to be recorded and used to adjust the field readings, which are performed by placing the electrode into an in-line flow cell without contact with air. The sample readings must be corrected by addition of the $\mathrm{Ag} / \mathrm{AgCl}$ reference potential at the sample temperature and the calibration correction. However, for samples collected in field it was determined that the redox potential of the Zobell solution at $26.3^{\circ} \mathrm{C}$ was $196 \mathrm{mV}$, which corresponds to a half-cell potential (electromotive force) equivalent to $230 \mathrm{mV}$. This result, added to the electromotive force, is equivalent to $426 \mathrm{mV}$, which is very close to the expected value for the correspondent Eh of $428 \mathrm{mV}$. Therefore, the difference was too small to be considered on values obtained in field.

The temperature readings were realized with a digital portable thermometer, as for dissolved oxygen determination; it was used the handset HANNA (HI 9146 model). Dissolved sulfide $\left(\mathrm{S}^{2-}\right)$ determinations were made using the HACH spectrophotometer, by applying the methylene blue method, where sulfide in samples reacts with ferric chloride and $N, N$-dimethyl-p-phenylenediamine oxalate producing methylene blue (CETESB 1978).

Dissolved carbon dioxide $\left(\mathrm{CO}_{2}\right)$ was measured like reported by Bonotto (2014), i.e. the titration method, where $25 \mathrm{~mL}$ of water sample were inserted into an Erlenmeyer flask and then added a phenolphthalein indicator solution sachet $(5 \mathrm{~g} / \mathrm{L})$. The solution was gently mixed, and then a $25 \mathrm{~mL}$ burette was filled to the zero mark with a $0.0227 \mathrm{~N}$ $\mathrm{NaOH}$ solution. The prepared sample was titrated, while the flask was gently shaked, until a pink color was formed and persisted for $30 \mathrm{~s}$. The $\mathrm{NaOH}$ reaction with $\mathrm{CO}_{2}$ occurred in two stages, first as a reaction of carbonic acid into bicarbonate and then into carbonate. Since the $\mathrm{CO}_{2}$ conversion into bicarbonate is complete at $\mathrm{pH} 8.3$, the phenolphthalein was used as a color indicator for the titration. Dissolved $\mathrm{CO}_{2}(\mathrm{mg} / \mathrm{L})$ was then calculated by multiplying the volume $(\mathrm{mL})$ used for titration by 40 . When a pink color is instantly formed by adding the phenolphthalein sachet, then the $\mathrm{CO}_{2}$ content corresponds to $0 \mathrm{mg} / \mathrm{L}$, and the titration process to change color is not necessary.

\section{Analytical methods}

\section{Chemical parameters}

The sampling flasks were transported to the laboratory, where aliquots were divided for analyzing the samples for the major compounds. The analyses of dissolved sodium and potassium were made using flame atomic absorption spectrometry (FAAS), while dissolved calcium, magnesium, 


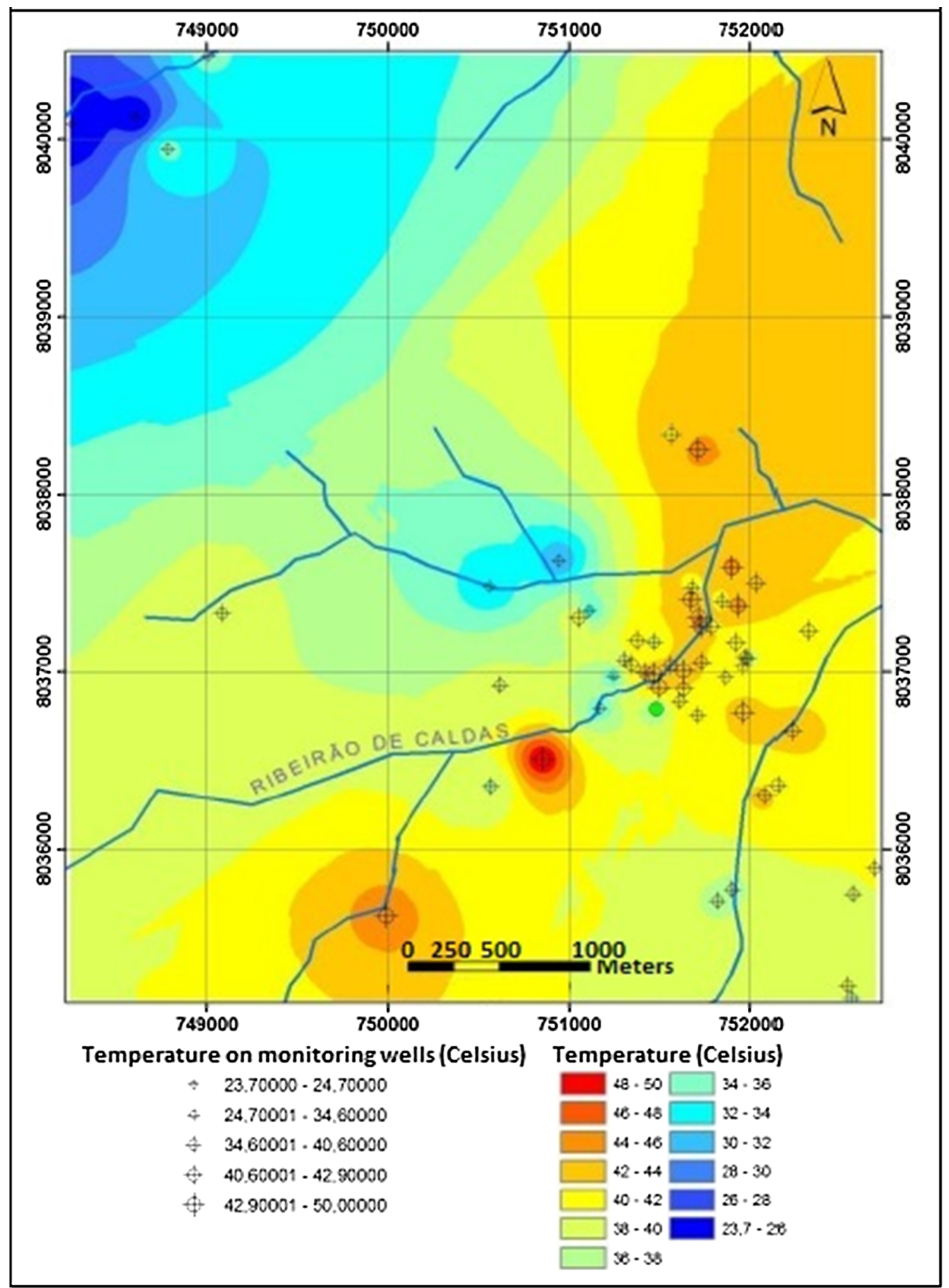

Fig. 6 Geothermal gradient contour based on data obtained from wells in Caldas Novas urban perimeter. Reproduce with permission from Almeida (2011) 


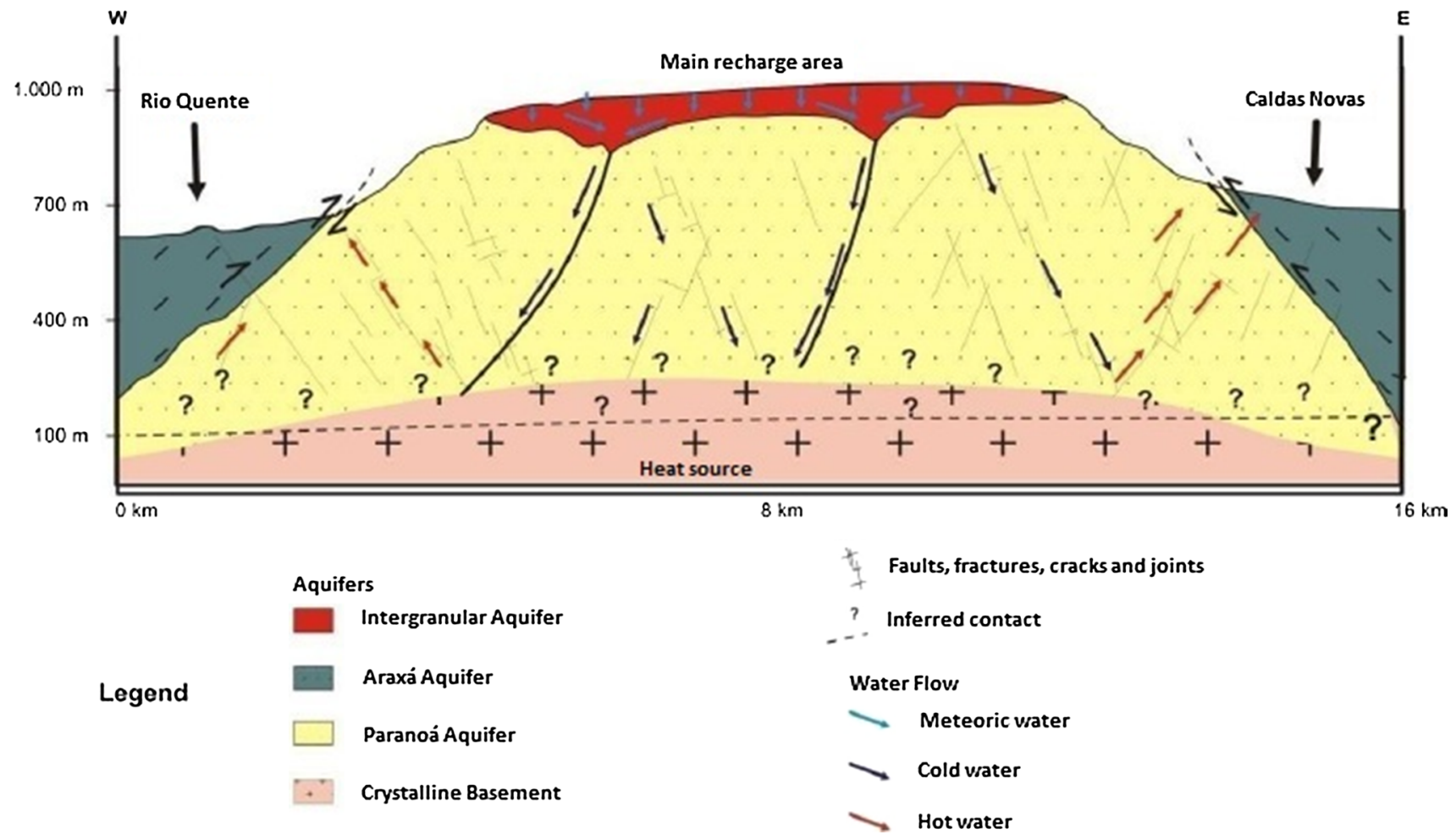

Fig. 7 Geothermal cross section of the study area, showing occurrence of aquifers, geothermal water recharge area, flow line, heat source and upwell channels. Reproduce with permission from (Andrade and Almeida 2012)

total iron and manganese were analyzed using inductively coupled plasma-atomic emission spectrometry (ICP-AES).

Ferrous iron, chloride, nitrate, phosphate and sulfate were determined by colorimetry after adding reagents to the samples that were able to produce colored complexes, read by a program stored in HACH DR/2000 spectrophotometer previously calibrated in variable concentrations at different wavelengths. Tannin and lignin chemical analysis was determined by colorimetry through HACH DR/2000 as well, and this was done specially because of the strong association of organic matter with uranium in several ores.

The concentration of carbonates and bicarbonates in the samples was determined by titration using a titrator with sulfuric acid standard solution to an end point evidenced by the color change of a standard indicator solution. This procedure uses a "blank" solution with boiled distilled water and an aliquot of the water sample, containing 0.005-0.04 milliequivalents ( $\mathrm{mEq}$ ), disposed on a beaker and placed against a white paper on the background for better visualization of color changes. A drop of phenolphthalein indicator is added to the sample and, if a red color appears, the sample is then titrated with a sulfuric acid solution until the red color vanishes. Then, 2 drops of methyl orange indicator are added to the solution and the titration continues until the first color changes into orange. Both volumes of titrant consumed must be recorded in order to calculate carbonate and bicarbonate concentrations according to the following equations:

$\mathrm{mEq} / \mathrm{L} \mathrm{CO}_{3}^{2-}=\left(2 y \cdot \mathrm{NH}_{2} \mathrm{SO}_{4} \cdot 1000\right) /$ titrated vol.

$\mathrm{mEq} / \mathrm{L} \mathrm{HCO}_{3}^{-}=\left[(x-2 y) \cdot \mathrm{NH}_{2} \mathrm{SO}_{4} \cdot 1000\right] /$ titrated vol.

Fluoride concentrations were determined using Tonetto and Bonotto (1999) methodology, where fluoride is potentiometrically measured after adding a known amount of ionic strength adjustor to each sample when necessary. Orion ionselective electrodes coupled to a digital meter were used, and standards containing variable concentrations of fluoride were utilized for preparing a calibration curve consisting of a logarithmic straight line involving the concentrations and potential readings.

Dissolved radon analysis were made by alpha spectrometry using AlphaGUARD (Genitron Radon Monitor), a device that provides simultaneous measurements of temperature, relative humidity, pressure and radon emanations in $\mathrm{Bq} / \mathrm{m}^{3}$. This equipment uses an alpha spectrometer that consists in a pulse optimized ionization chamber where the gas is diffused into a cylindrical chamber with a glass fiber filter that retains all radon decay products (Artur et al. 2013). This analysis begins with the injection of $100 \mathrm{~mL}$ of sample in the emanation vessel, and then the device is set to operate at a $0.03 \mathrm{~L} / \mathrm{min}$ flow rate. For each sample, it required a 30 
Fig. 8 Geothermal gradient contours at the State of Goiás. Reproduce with permission from Ferreira (2003)

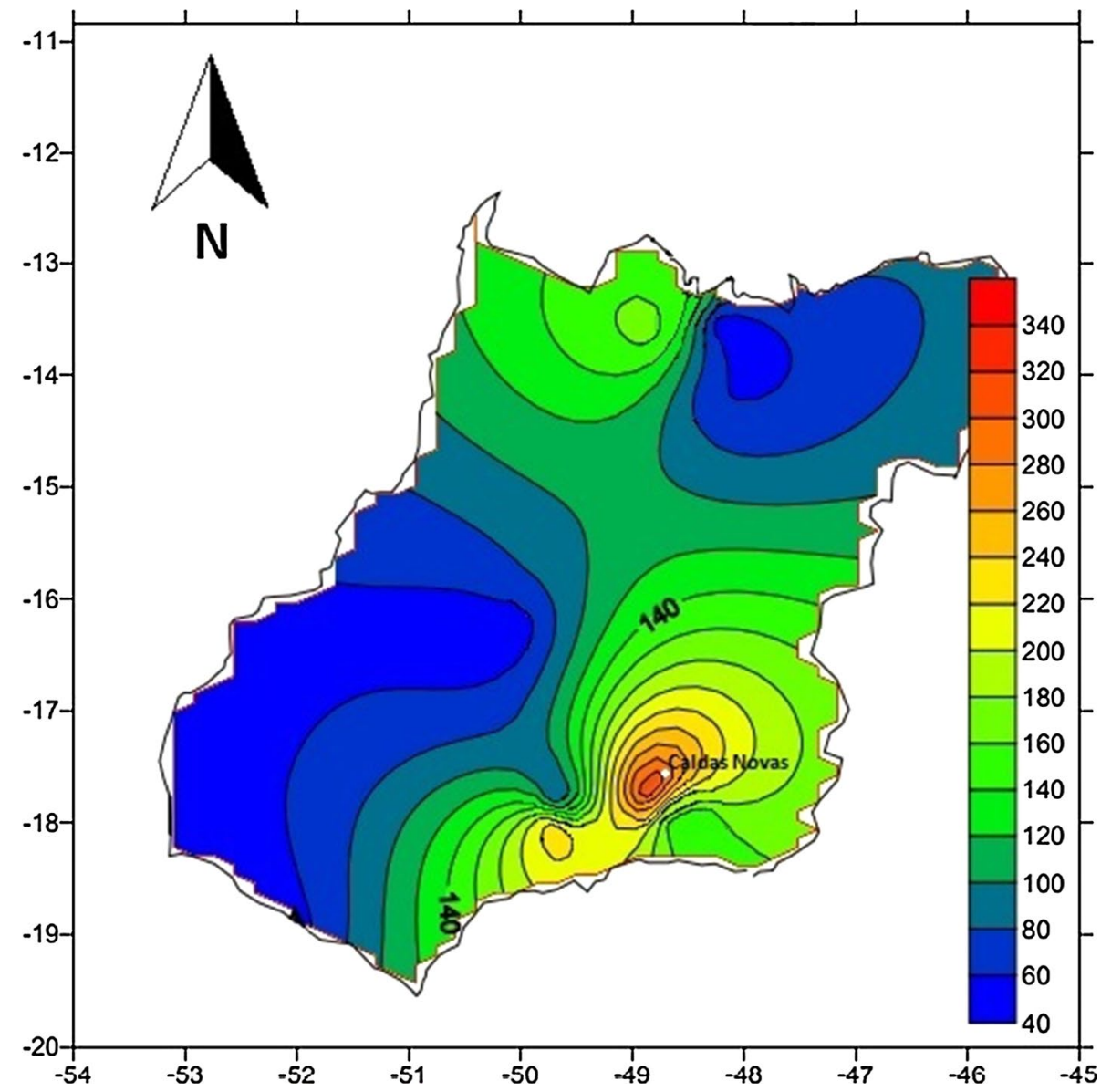

min measurement, from which the first $10 \mathrm{~min}$ is required to make the suction through the pump and the remaining $20 \mathrm{~min}$ are used to read the decay of radon activity (Barbosa 2013). Once the radon content reading is done, each water sample is removed and the device goes through an activated charcoal cleaning cylinder. This process allows the radon to be removed from the AlphaGUARD system, in order to prevent contamination of subsequent samples.

Uranium isotopic analysis $\left({ }^{238} \mathrm{U}\right.$ and $\left.{ }^{234} \mathrm{U}\right)$ was made following the method described by Bonotto (2004), which uses alpha spectrometry to characterize uranium isotopes in samples employing thin sources to avoid absorption of alpha particles by the deposited layer. The samples were subjected to several separation steps, in order to remove interfering elements, until stainless steel disks containing the extracted uranium were prepared. Water samples collected in the field were stored in polyethylene bottles and transported to the laboratory for evaluating the $\mathrm{U}$ isotopes. The aliquots ( $15 \mathrm{~L}$ ) for $\mathrm{U}$ analysis were acidified to $\mathrm{pH}$ less than 2 on using $\mathrm{HCl}$, about $500 \mathrm{mg}$ of $\mathrm{FeCl}_{3}$ plus $3.39 \mathrm{dpm}$ of ${ }^{232} \mathrm{U}$ were added, and $\mathrm{U}$ was co-precipitated on $\mathrm{Fe}(\mathrm{OH})_{3}$ by increasing the $\mathrm{pH}$ to 7-8 through addition of concentrated $\mathrm{NH}_{4} \mathrm{OH}$ solution; the precipitated was recovered and dissolved in $8 \mathrm{M} \mathrm{HCl}$, and $\mathrm{Fe}^{3+}$ was extracted into an equal volume of isopropyl ether. Then, the analytical protocol described by Bonotto (2006) was utilized for acquiring the $\mathrm{U}$ content and ${ }^{234} \mathrm{U} /{ }^{238} \mathrm{U}$ Activity Ratio (AR) data. One rainwater sample (1-rain) collected during a rainfall event was also analyzed for physicochemical and chemical characterization in order to compare with the acquired thermal waters database. Tables 1, 2, 3, and 4 report all the results of the measurements.

\section{Results and discussion}

\section{Physicochemical analysis}

The collected water samples showed variable temperatures due to different sampling sites and situations. Sample 1-rain, yielded $22.9^{\circ} \mathrm{C}$, whereas samples 5,7 and 8 yielded $24.8^{\circ} \mathrm{C}$, $33.6^{\circ} \mathrm{C}$ and $32.7^{\circ} \mathrm{C}$, respectively. The remaining groundwater samples reached temperatures between $28.6^{\circ} \mathrm{C}$ and $55.9^{\circ} \mathrm{C}$.

The conductivity values in the water samples varied between 30 and $220 \mu \mathrm{S} / \mathrm{cm}$. The groundwater samples, endowed with higher temperatures, showed higher conductivity values, as river waters and rainwater samples exhibited 
low conductivity values, coherent with temperature and small amount of dissolved salts.

Surface waters typically contain less than $10 \mathrm{mg} / \mathrm{L}$ of dissolved $\mathrm{CO}_{2}$, while groundwater may contain several hundreds of $\mathrm{mg} / \mathrm{L}$, particularly if very deep (APHA 2005). Sample 6 showed the highest measured value for dissolved $\mathrm{CO}_{2}$, equivalent to $580 \mathrm{mg} / \mathrm{L}$ while the remaining groundwater sample (except for sample 4.1) yielded values were lower than expected. Samples 7 and 8 showed relatively high dissolved $\mathrm{CO}_{2}$ values in surface waters.

Dissolved oxygen analysis showed a higher value for sample 5, equivalent to $6.57 \mathrm{mg} / \mathrm{L} \mathrm{O}_{2}$, probably due to the location of the monitoring point in a site where the river was moving at a higher speed or also due to rainfall events during sampling. Sample 8 was collected in a drain located downstream of a sewage release and presented the second highest dissolved oxygen content $\left(5.90 \mathrm{mg} / \mathrm{L} \mathrm{O}_{2}\right)$. However, this value does not differ much from the results obtained for other samples, possibly because the oxygen solubility in water increases with decreasing temperature, i.e., cold water retains more oxygen than warmer water.

The rock types that comprise the reservoirs of Caldas Novas Thermal Complex do not have well recognized sulphurous minerals in their composition; however, values found in water samples ranged from 0 to $12 \mathrm{mg} / \mathrm{L}$ sulfide. The highest value was found in sample $6(12 \mathrm{mg} / \mathrm{L})$, followed by sample $8(5 \mathrm{mg} / \mathrm{L})$, in this case probably associated to discharges of domestic sewage downstream of the sampling site or so, due to mixing processes. Samples 1-thermal, 2.1, 4.1 and 7 showed concentration of $1 \mathrm{mg} / \mathrm{L}$, whereas the other samples exhibited values were below the detection limit of $3 \mu \mathrm{g} / \mathrm{L} \mathrm{S}^{2-}$.

The water samples provided $\mathrm{pH}$ values ranging between 6.0 and 8.0, which is consistent with what is established by Ordinance 518 of Brazilian Ministry of Health (Brasil 2005) i.e. $\mathrm{pH}$ values for public supply between 6.0 and 9.5

The Eh values oscillated between 105 and $203 \mathrm{mV}$, except for sample 6, which corresponded to $0 \mathrm{mV}$. This is due to the fact that this sample contains more sulfur than others, featuring a reducing environment that displays electrons excess.

From data obtained with Eh and $\mathrm{pH}$ values, an Eh $v s . \mathrm{pH}$ diagram was elaborated, using an upper oxidation limit and a lower reducing limit to the water. Positive Eh values often indicate oxidative conditions, while negative values indicate electrons availability or reducing conditions. According to the diagram of Fig. 9, sample 6 (with the highest dissolved $\mathrm{S}^{2-}$ ), showed more reducing conditions. Sample 5, collected from Pirapitinga river, located just above the transitional contour, suggesting oxidizing trends. Sample 1-rain had the lowest $\mathrm{pH}$ value when compared to others and so was located more to the left of the diagram. Samples 4.1, 4.2, 4.3 and 4.4, collected from close sampling spots, provided similar values for $\mathrm{Eh}$ and $\mathrm{pH}$ and were all plotted above of

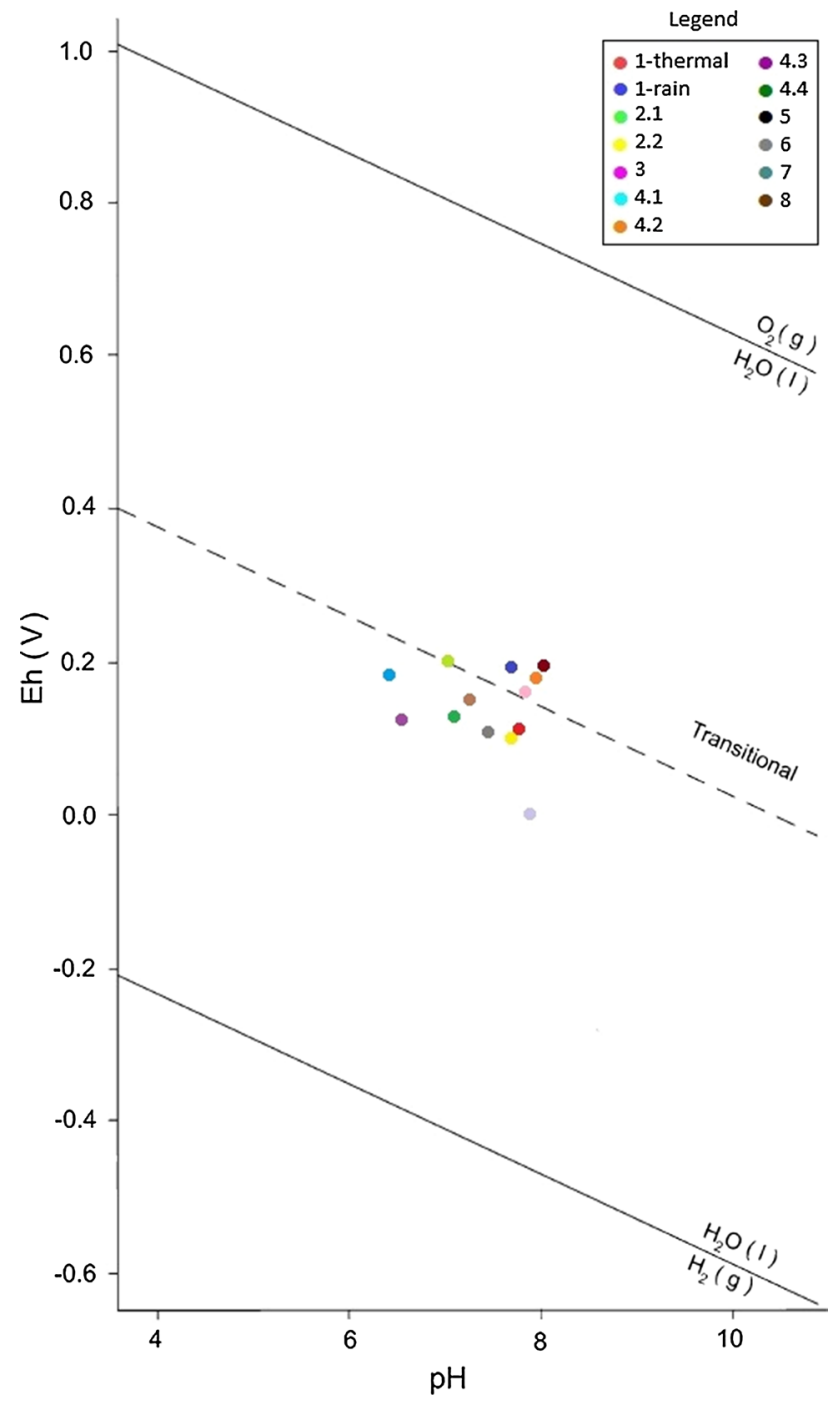

Fig. 9 Eh $\times$ pH diagram of groundwaters, rainwater and surface waters from the Caldas Novas Thermal Complex

the transitional line, with more oxidizing trends than others samples. The remaining samples were located below the transitional limit, indicating more reducing conditions and corresponding to an expected behavior for groundwater samples because of their confinement in anoxic regions. Under such conditions, the Eh values reduce when compared to those of the surface waters that are in constant contact with the oxidizing atmosphere (Jardim 2014).

\section{Chemical analysis}

Great sodium concentrations are common in several aquifer systems, however, the results obtained in this study were low due to a lack of sodium minerals in Caldas Novas 
region. Only sample 6 provided an enhanced value compared to other samples $\left(8.5 \mathrm{mg} / \mathrm{L} \mathrm{Na}^{+}\right)$, but it is still considered low relatively to the guideline reference value of $200 \mathrm{mg} / \mathrm{L}$ for human consumption (Brasil 2005).

Potassium concentrations did not exceed $2.4 \mathrm{mg} / \mathrm{L}$, and this is mainly because of the geological framework of Caldas Novas region that does not count on potassium-rich rocks. Potassium only appears in local geology as small biotite and tourmaline crystals, occurring in pelitic-carbonated units of Paranoá Group and biotite-chlorite-schists of Araxá Group, in which biotite suffered destabilization, being transformed into chlorite by retrometamorphic processes (Campos et al. 2009).

The cations $\mathrm{Ca}^{2+}$ and $\mathrm{Mg}^{2+}$ were widely present in the analyzed samples. Both are responsible for hardness in those waters, and its source is mainly from the dissolution of limestone and dolomite by carbon dioxide present in water. Thus, it is very common to find groundwater with high hardness than surface water. There are no studies relating hardness in waters with human health problems, though the Ordinance 2914 of Brazilian Ministry of Health (Brasil 2011) sets a standard sum of calcium and magnesium concentrations as a maximum value of $500 \mathrm{mg} / \mathrm{L}$. However, none sample reached this value.

The analyzed water samples didn't show any manganese concentration above the standard set for human consumption of $0.1 \mathrm{mg} / \mathrm{L}$, according to the Brazilian Ministry of Health (Brasi 2011). Except for samples 1 and 8, the remaining samples resulted in such low concentrations of manganese $\left(<0.7 \mu \mathrm{g} / \mathrm{L} \mathrm{Mn}^{2+}\right)$ that ICP-AES method was not able to read.

Nitrate analysis resulted in low concentrations, not exceeding $2 \mathrm{mg} / \mathrm{L} \mathrm{NO}_{3}{ }^{-}$. This value is also below the guideline reference value of $10 \mathrm{mg} / \mathrm{L}$ for human consumption set by the Brazilian Ministry of Health (Brasil 2005).

Phosphate analysis provided the highest concentrations of $0.59-0.60 \mathrm{mg} / \mathrm{L}$ as obtained for samples 7 and 8 , both collected from the same river and downstream of sewage discharges. Sample 2.2, whose temperature was the highest recorded, also yielded a high phosphate concentration when compared to other thermal waters. Since phosphate minerals have not been clearly found in rocks of Caldas Novas region, it is presently unknown the potencial source of this anion to such hot waters.

The sulfates concentration in drinking water in Brazil should remain below $250 \mathrm{mg} / \mathrm{L}$, according to the standards set by the Brazilian Ministry of Health (Brasil $2005)$. The analyzed samples provided a very similar result for sulfate $(1 \mathrm{mg} / \mathrm{L})$, except for sample 6 , whose concentration reached $8 \mathrm{mg} / \mathrm{L} \mathrm{SO}_{4}{ }^{2-}$.

Lazzerini and Bonotto (2014) reported the average Si content expected for different compartments like rainwater $(0.7 \mathrm{mg} / \mathrm{L})$, tropical rivers $(9.5 \mathrm{mg} / \mathrm{L})$, and tropical aquifers $(9.8 \mathrm{mg} / \mathrm{L})$. Based on these values, the rainwater sample showed a silica concentration implying on a $\mathrm{Si}$ value slightly higher than $0.7 \mathrm{mg} / \mathrm{L}$, whereas the surface water samples (5, 7 and 8 ) provided results below 9.5 $\mathrm{mg} / \mathrm{L}$. As for the samples of hot springs, those collected within the Lagoa Quente Park area provided the greatest results for silica concentration, reaching $19 \mathrm{mg} / \mathrm{L}$ (sample 4.3). This sample, despite having a lower-temperature value than the other samples, showed the highest measured $\mathrm{pH}$ value (8.02) of all samples, which is a crucial parameter for increasing the silica solubility (Mason 1966).

The chloride anion is found in groundwater mainly by water percolation through soils and rocks, and in surface water through sewage discharges. The analyzed samples results were low for chloride, not exceeding $2.1 \mathrm{mg} / \mathrm{L} \mathrm{Cl}^{-}$, that is a value well bellow the maximum permissible concentration of $250 \mathrm{mg} / \mathrm{L}$ established by the Brazilian Ministry of Health (Brasil 2005).

Fluoride is an anion commonly found in groundwater, but the analyzed samples provided poor results, not exceeding $0.05 \mathrm{mg} / \mathrm{L} \mathrm{F}^{-}$. The Brazilian Ministry of Health allows waters destined to public supply to contain concentrations up to $1.5 \mathrm{mg} / \mathrm{L}$ (Brasi 2011), in order to avoid dental fluorosis problems.

In groundwaters, iron is usually found as ferrous iron $\left(\mathrm{Fe}^{2+}\right)$, however, the data obtained in them showed that only sample 8 provided a value above the detection limit $\left(0.023 \mathrm{mg} / \mathrm{L} \mathrm{Fe}^{2+}\right)$.

The total iron analysis resulted in low values, well below the maximum concentration permitted by the Brazilian Ministry of Health (Brasil 2005) which is $0.3 \mathrm{mg} / \mathrm{L}$. Samples 5 and 8 , both collected from rivers during the rainy month of November 2014, yielded the highest concentrations, respectivaly 0.008 and $0.019 \mathrm{mg} / \mathrm{L}$. This may be related to the fact that the iron levels usually increase during rainy seasons, due to the entrainment of soil and margins erosion (CETESB 2014).

Tannins may be found predominantly in organic industrial wastes such as tanneries, while lignin occurs in effluents discharged by pulp, paper and wood industries. Most water samples exhibited results below the detection limit of $0.07 \mathrm{mg} / \mathrm{L}$ of tannic acid, except for sample 5, whose concentration reached $0.1 \mathrm{mg} / \mathrm{L}$.

Both carbonates and bicarbonates analyses have been performed, but only bicarbonates were detected on collected water samples. The results showed a clear pattern where bicarbonate is the predominant anion in all water samples. These data are compatible with measured $\mathrm{pH}$ values found in field, which were slightly higher than expected for each water source. 


\section{Hydrochemical characterization}

The diagrams in Figs. 10, 11, and 12 were generated by the AqQA software, developed by the company RockWare. Using data gathered from physical-chemical parameters (Table 1) and dissolved constituents (Table 2), a Piper diagram (Fig. 10) was created in order to represent the composition of the several water samples. The thermal water samples yielded very similar results, all of them very rich in calcium and bicarbonate, and poor in sodium, potassium, sulfate and chloride. The 1-rain sample and sample 5, collected from Pirapitinga river, displayed higher sodium and potassium levels compared to dissolved calcium and magnesium contents, as well as bicarbonate as the predominant anion. Sodium, potassium and calcium cations from sample 6 were balanced, and despite being collected from a sulphurous source, the bicarbonate anion still prevailed over the sulfate. In summary, the thermal waters from Caldas Novas can be classified as calcic-bicarbonated, a typical pattern of shallow, fresh groundwaters. The samples from Pirapitinga river and the sulphurous spring were both classified as sodic-bicarbonated, while the rain water was classified as potassic-bicarbonated.

A Schoeller diagram (Fig. 11) was also created from the results of the dissolved constituents where the main ionic concentrations were plotted on six equally spaced logarithmic scales, and the points so plotted were then joined by straight lines. This diagram gives the absolute concentration of each ion and, in addition, the concentration differences among various analyses of groundwater. As a result of the semi-logarithmic arrangement, if a straight line joining two points of two ions in a sample of water is parallel to another straight line joining two points of the same two ions in a second sample of water, the ratio of the ions in the two analyses is equal (Bowen 1986). The Schoeller diagram also showed that $\mathrm{Ca}^{2+}$ and $\mathrm{HCO}_{3}^{-}$are the dominant ions in the study

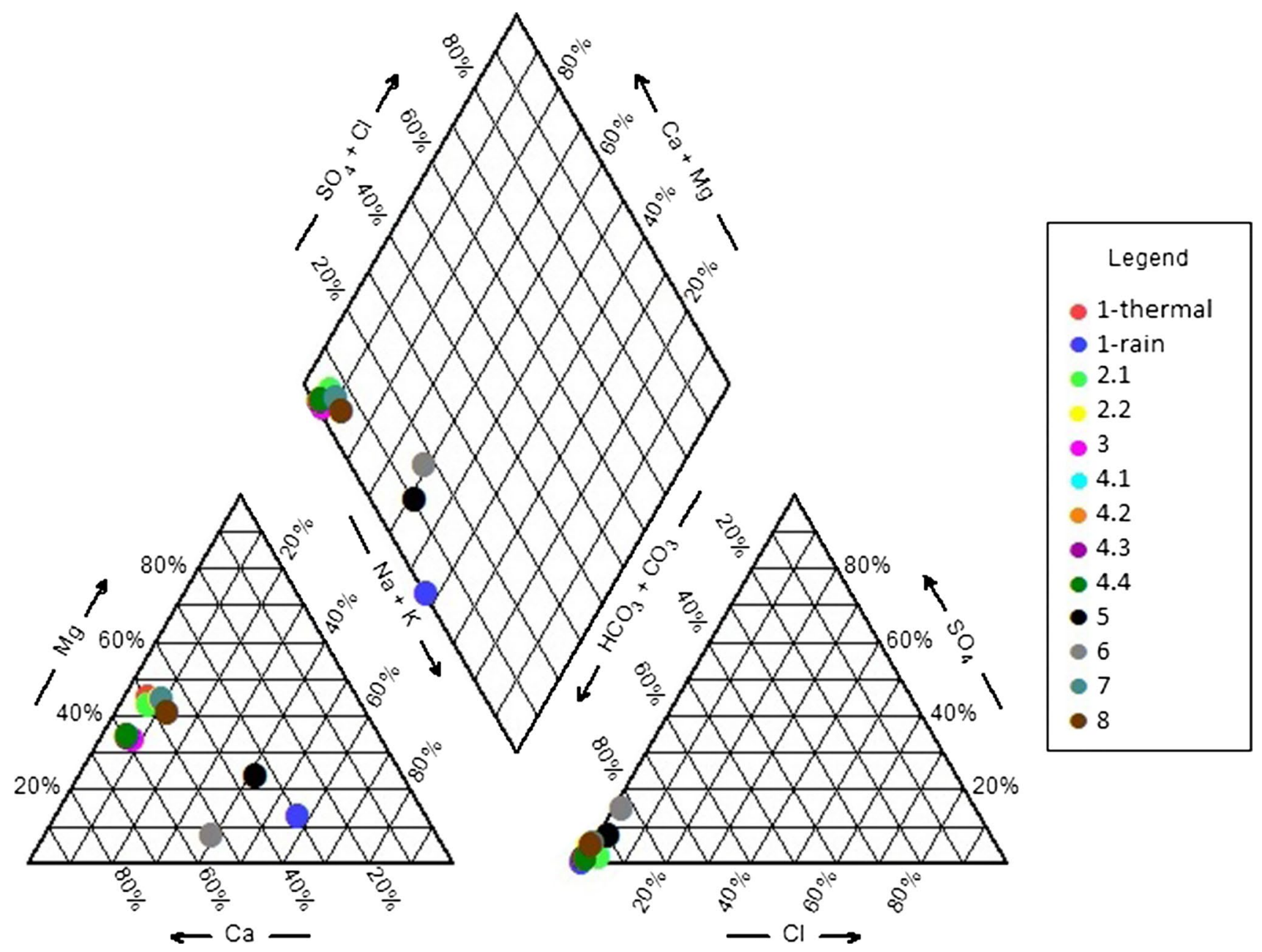

Fig. 10 Data of the chemical composition of groundwaters, rainwater and surface waters from the Caldas Novas Thermal Complex plotted on a Piper diagram 
Fig. 11 Data of the chemical composition of groundwaters, rainwater and surface waters Complex plotted on a Schoeller diagram from the Caldas Novas Thermal
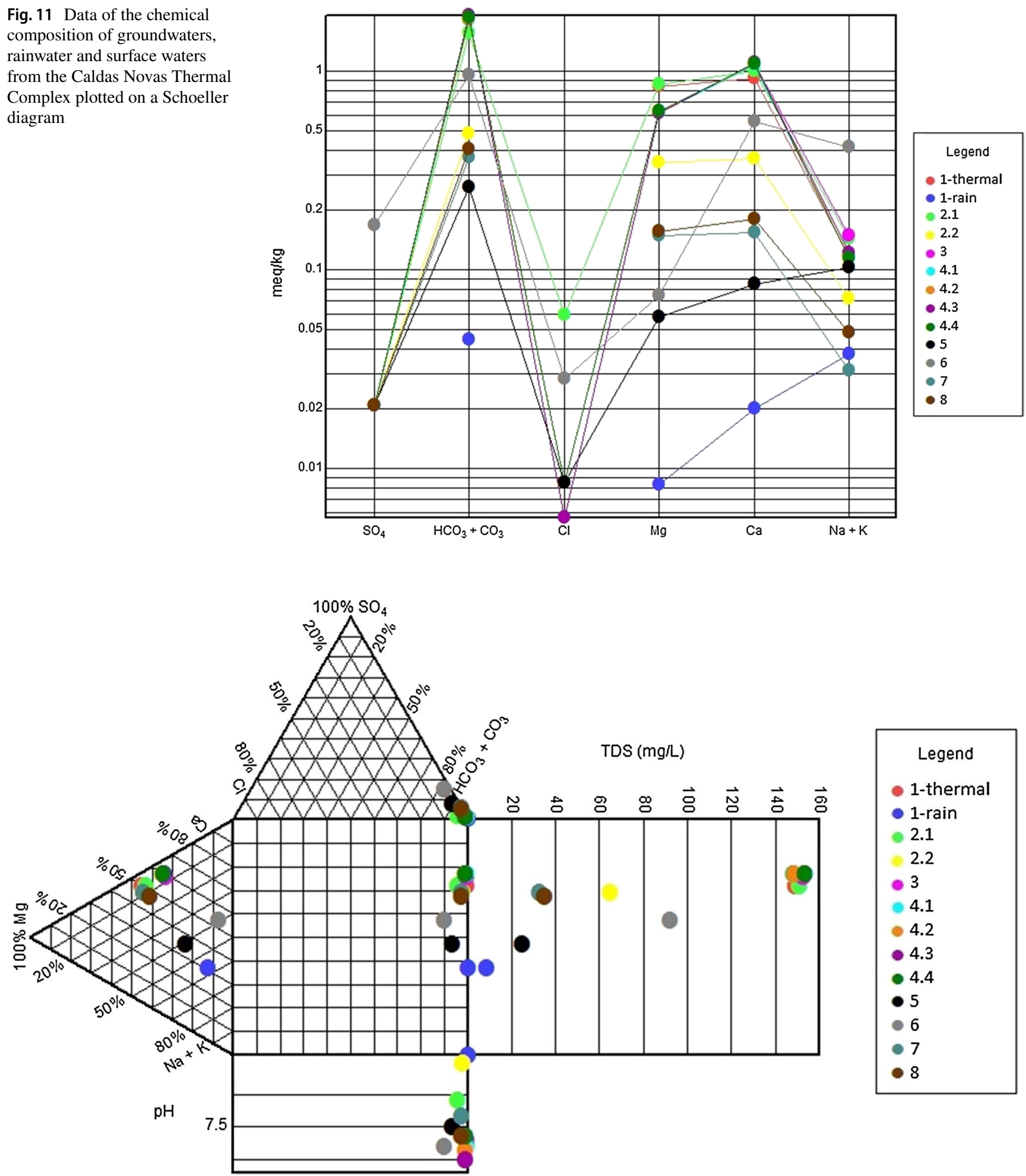

Fig. 12 Data of the chemical composition of groundwaters, rainwater and surface waters from the Caldas Novas Thermal Complex plotted on a Durov diagram

area. The dominant $\mathrm{Ca}-\mathrm{HCO}_{3}$ groundwater types occur due to the carbonates dissolution process of the Paranoá Group rocks, in contrast with the rainwater composition that is of
$\mathrm{Na}-\mathrm{K}-\mathrm{HCO}_{3}$ type. These $\mathrm{Ca}-\mathrm{HCO}_{3}$ waters represent a permanent hardness of the groundwater. 


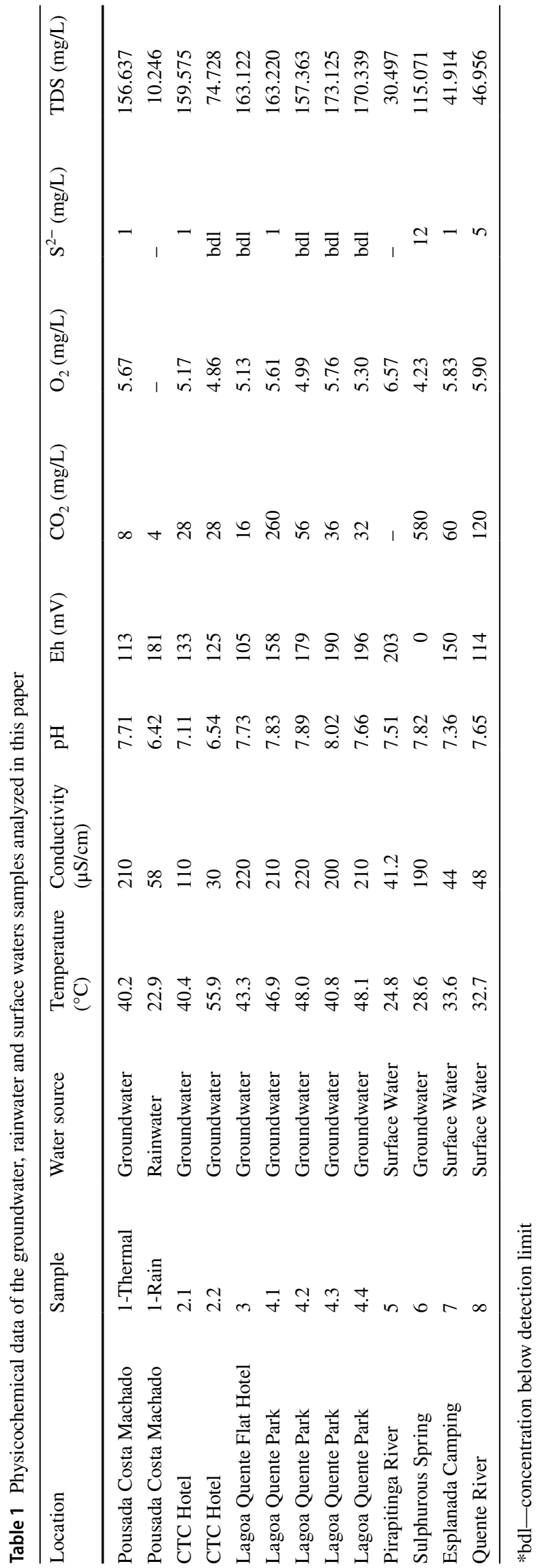

Additionally, a Durov diagram (Fig. 12) was created from the results of the dissolved constituents. It is a composite plot consisting of 2 ternary diagrams where the cations of interest, also including TDS $(\mathrm{mg} / \mathrm{L})$ and $\mathrm{pH}$ data added to the sides of the binary plot of total cation vs. total anion concentrations to allow further comparisons. The ternary anion diagram has classified all water samples as bicarbonated, which also reflects on the $\mathrm{pH}$ levels, whose trends are mostly alkaline, except for samples 2.2 and 1-rain, which display acid tendency. The TDS field indicates that the thermal waters displayed higher values in relation to the other samples. However, all water samples exhibited TDS values lower than the maximum of $1000 \mathrm{mg} / \mathrm{L}$ as established by the Brazilian Ministry of Health (Brasil 2005).

\section{Radionuclide analysis}

The thermal waters radon analysis results initially reported in $\mathrm{Bq} / \mathrm{m}^{3}$ (Table 3) were converted to $\mathrm{Bq} / \mathrm{L}$. According to article 35 from the Brazilian Code of Mineral Waters (decree law 7.841/1945), (Brasil 1945), mineral waters can only be considered weakly radioactive when radon content is between 5 and 10 mache unit per liter (MU), at $20^{\circ} \mathrm{C}$ and $706 \mathrm{mmHg}$. Eleven samples from Caldas Novas (GO) were analyzed for dissolved radon and none indicated radioactivity values above $5 \mathrm{MU}$, thus, they are non-radioactive. According to Campos et al. (1980), such values discard the possibility of local hydrothermalism arising from disintegrations related to radioactive minerals.

The results for dissolved uranium concentration in underground waters (Table 4) varied between 0.004 e $0.79 \mu \mathrm{g} / \mathrm{L}$ $\mathrm{U}$ and the ${ }^{234} \mathrm{U} /{ }^{238} \mathrm{U}$ activity ratio (AR) between 0.40 and 28.17. The Brazilian Ministry of Health (Brasi 2011), establishes a limit of $0.03 \mathrm{mg} / \mathrm{L}$ as reference for $\mathrm{U}$ ingestion in drinking water. Thus, all analyzed samples provided values below the set limit and failed to classify as radioactive concerning uranium content.

\section{Conclusion}

The results reported in this study contributed to a better understanding of the Caldas Novas thermal waters hydrochemistry. Neotectonics plays a fundamental role in the heating of such waters and the region's hydrothermalism is exclusively due to the geothermal gradient, ruling out any connections to volcanic processes and radioactive minerals disintegration.

Fractures are open and deep enough to guarantee water infiltration $1 \mathrm{~km}$ below the surface at Caldas Novas Dome, the region's main recharge area. Thermal waters temperatures registered at Caldas Novas Dome west side, Rio Quente's region, 


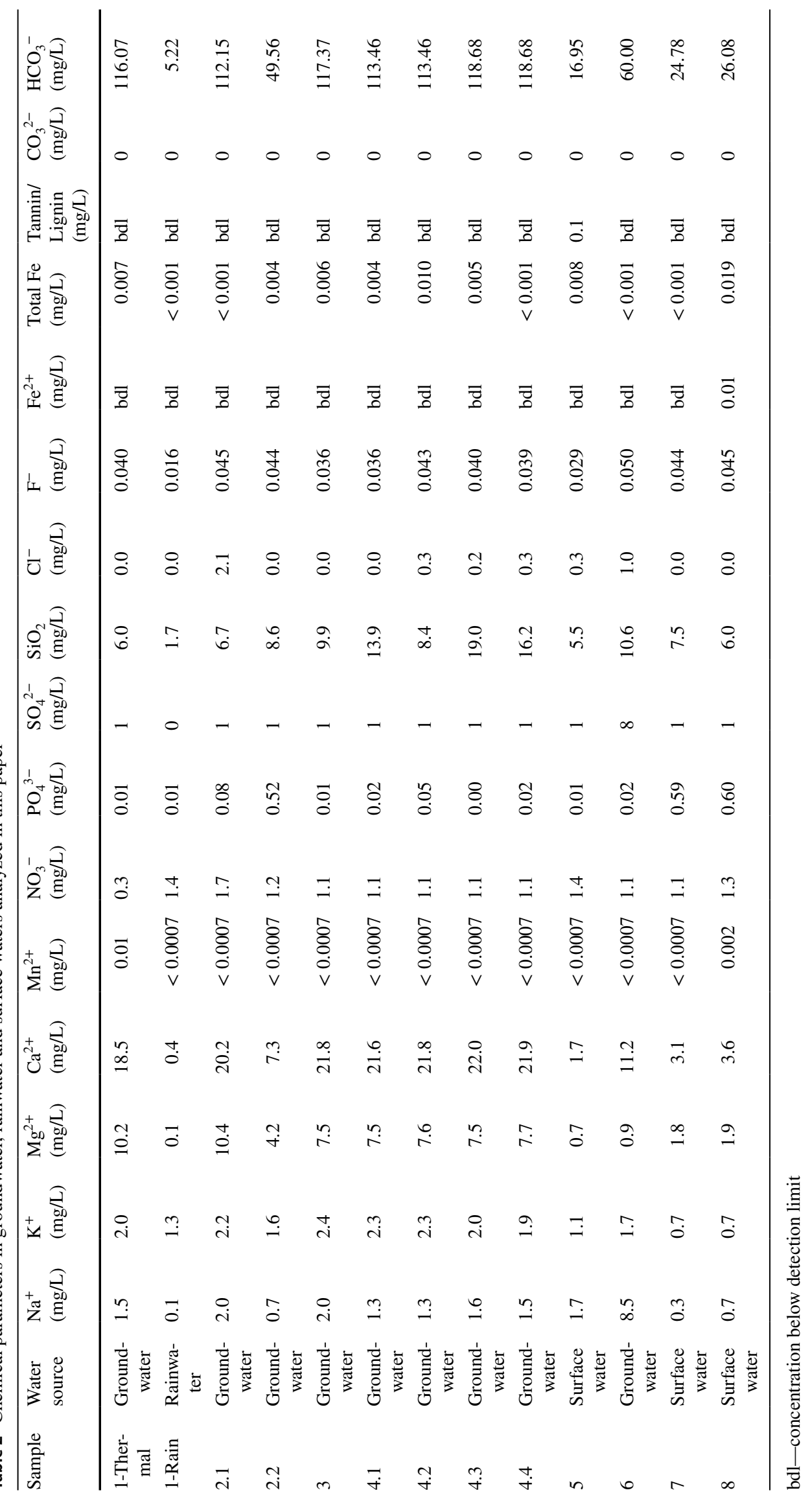


Table 3 Data for dissolved radon parameters in groundwater, rainwater and surface waters analyzed in this paper

\begin{tabular}{|c|c|c|c|c|c|c|c|}
\hline Sample & $\mathrm{Rn}\left(\mathrm{Bq} / \mathrm{m}^{3}\right)$ & $\begin{array}{l}\text { Spring tempera- } \\
\text { ture }\left({ }^{\circ} \mathrm{C}\right)\end{array}$ & $\begin{array}{l}\text { Rn solubility } \\
\text { coefficient }\end{array}$ & Measured $(\mathrm{Bq} / \mathrm{L})$ & $\begin{array}{l}\text { Time elapsed } \\
(\mathrm{min})\end{array}$ & $\begin{array}{l}\text { Corrected value } \\
(\mathrm{Bq} / \mathrm{L})\end{array}$ & $\begin{array}{l}\text { Corrected } \\
\text { value (ME) }\end{array}$ \\
\hline 1-Thermal & $1020 \pm 134$ & 40.2 & 0.162 & 10.576 & 5817 & 21.985 & 1.717 \\
\hline 2.1 & $1200 \pm 142$ & 40.4 & 0.162 & 12.385 & 5767 & 25.584 & 1.998 \\
\hline 2.2 & $415 \pm 83$ & 55.9 & 0.130 & 4.230 & 5817 & 8.793 & 0.687 \\
\hline 3 & $824 \pm 113$ & 43.3 & 0.155 & 8.500 & 5756 & 17.534 & 1.369 \\
\hline 4.1 & $435 \pm 80$ & 46.9 & 0.150 & 4.480 & 5807 & 9.301 & 0.726 \\
\hline 4.2 & $343 \pm 72$ & 48.0 & 0.140 & 3.528 & 5880 & 7.392 & 0.577 \\
\hline 4.3 & $128 \pm 36$ & 40.8 & 0.162 & 1.299 & 6758 & 3.039 & 0.237 \\
\hline 4.4 & $510 \pm 79$ & 48.1 & 0.140 & 5.250 & 6830 & 12.396 & 0.968 \\
\hline 6 & $2470 \pm 225$ & 28.6 & 0.205 & 25.717 & 6837 & 60.779 & 4.747 \\
\hline 7 & $55 \pm 43$ & 33.6 & 0.180 & 0.524 & 5860 & 1.095 & 0.085 \\
\hline 8 & $18 \pm 8$ & 32.7 & 0.182 & 0.174 & 5902 & 0.365 & 0.028 \\
\hline
\end{tabular}

Table $4 \mathrm{U}$ isotopes data obtained in groundwater, rainwater and surface waters analyzed in this paper

\begin{tabular}{|c|c|c|c|c|c|c|c|}
\hline \multirow[t]{3}{*}{ Sample } & \multirow[t]{3}{*}{ Volume (L) } & \multirow[t]{3}{*}{ Live time (s) } & \multicolumn{3}{|c|}{ Counting rate } & \multirow{3}{*}{$\begin{array}{l}\text { Activity ratio } \\
\left({ }^{234} U /{ }^{238} U\right)\end{array}$} & \multirow[t]{3}{*}{$\mathrm{U}(\mu \mathrm{g} / \mathrm{L})$} \\
\hline & & & \multicolumn{3}{|c|}{ (Gross area) } & & \\
\hline & & & U-238 & U-234 & U-232 & & \\
\hline 1-Thermal & 15 & $30,883.48$ & 14 & 69 & 75 & 4.74 & 0.07 \\
\hline 2.1 & 15 & $86,133.46$ & 19 & 105 & 53 & 23.42 & 0.03 \\
\hline 2.2 & 15 & $107,652.40$ & 13 & 23 & 245 & 5.05 & 0.01 \\
\hline 3 & 15 & $107,612.18$ & 19 & 33 & 60 & 2.45 & 0.07 \\
\hline 4.1 & 15 & $196,149.68$ & 9 & 13 & 45 & 28.17 & 0.004 \\
\hline 4.2 & 15 & $86,105.48$ & 131 & 88 & 167 & 0.67 & 0.30 \\
\hline 4.3 & 15 & $333,435.00$ & 24 & 68 & 202 & bdl & bdl \\
\hline 4.4 & 15 & $77,632.64$ & 5 & 7 & 17 & 4.32 & 0.04 \\
\hline 6 & 15 & $108,695.00$ & 2 & 1 & 19 & bdl & 0.04 \\
\hline 7 & 15 & $658,815.38$ & 38 & 88 & 19 & bdl & 0.79 \\
\hline 8 & 15 & $64,115.88$ & 22 & 15 & 109 & 0.40 & 0.06 \\
\hline
\end{tabular}

bdl—concentration below detection limit were 32.7 and $33.6{ }^{\circ} \mathrm{C}$, while thermal waters on the east side, Caldas Novas region, registered higher temperatures, varying between 40.2 and $55.9^{\circ} \mathrm{C}$. Such results are compatible with isotopic data from other studies, which indicate that waters from Caldas Novas Dome west portion are younger $(600-800$ years old) and colder, in contrast to waters from Caldas Novas Dome east portion that are older (over 2000 years old) and warmer.

In spite of the higher registered temperatures, the chemical analyses of the thermal samples have confirmed the expected low mineralization, coinciding with previous works in the same region.

Thermal waters sampled from parks and hotels provided similar physicochemical information, pointing out to the possibility of same provenance. The sulfurous water source (sample 6), whose temperature was about $20^{\circ} \mathrm{C}$ lower than the other thermal waters, registered higher values for radon, sulfide, sulfate, sodium and fluoride. This can be related to the fact that lower-temperature thermal waters retain more gases, such as $\mathrm{CO}_{2}$ and $\mathrm{S}^{2-}$, or can also evidence the mixture between two or more kinds of water, which granted this sample a higher concentration of dissolved solids, associated with a lower temperature.

For drainage waters, higher chemical variations were to be expected due to contact with several lithologic types and superficial contamination problems. However, since these waters are naturally colder and the lithologic types traverse across the region are less reactive, the ion availability was lower when compared to thermal waters. Lower interaction times between water and rock in these environments must be also taken into account. The only component setting Pirapitinga river's water apart from the others was tannic acid.

The rainwater composition is a by-product of atmospheric air composition. The chemical analyses revealed: potassium (as the main cation), sodium, calcium, magnesium, 
nitrate, phosphate, fluoride, silica and bicarbonate (as the main anion). The bicarbonate concentration in rainwater amounted to more than half of the sample's dissolved solids, which was probably responsible for the higher-than-expected $\mathrm{pH}$ value for rainfall, which is usually around 5.5.

Except for the sulphurous spring (sample 6), which presented a distinctive sulfur odor, all other samples were odorless. None of them presented materials in suspension, and the sample with higher turbidity came from Pirapitinga river, due to heavy precipitation before sampling.

The radionuclides analysis showed that the thermal waters don't have high levels of dissolved radon or uranium, not being classified as radioactive and ruling out the possibility of linking hydrotermalism with disintegration of radioactive isotopes.

Acknowledgements CAPES (Coordination for the Development of Higher Education Personnel) in Brazil is greatly thanked for the scholarship to ML.

\section{References}

Almeida L (2011) Study of the applicability of artificial recharge techniques in groundwaters for sustainability of thermal waters in Caldas Novas region (GO). PhD Thesis, University of Brasilia, Brasilia

Andrade AM, Almeida L (2012) Behavior of potentiometric levels of Caldas Novas thermal aquifer (GO) and restriction and control measures applied by the national department of mineral production (DNPM). Águas Subterrâneas 26(1):99-112

APHA (American Public Health Association) (2005) Standard Methods, 21 st edn., Method 4500-CO2 C. ASTM D 513-82, Total and Dissolved Carbon Dioxide in Water, Test Method E. APHA, Washington

Artur AC, Bonotto DM, Amaral PGQ, do Galembeck TMB (2013) Methodology for quantifying the inhalation of radon gas in ornamental rocks. Geociências 32(1):166-180

Barbosa EQ (2013) Radon as a soil contamination indicator for hydrocarbons. Monograph, UNESP, Rio Claro

Bonotto DM (2004) Radioactivity in waters: from England to Guarani. Ed. UNESP, São Paulo

Bonotto DM (2006) Hydro(radio)chemical relationships in the giant Guarani aquifer, Brazil. J Hydrol 323:353-386

Bonotto DM (2012) A comparative study of aquifer systems occurring at the Paraná sedimentary basin, Brazil: major hydrochemical trends. Environ Earth Sci 67:2285-2300

Bonotto DM (2014) ${ }^{222} \mathrm{Rn},{ }^{220} \mathrm{Rn}$ and other dissolved gases in mineral waters of southeast Brazil. J Environ Radioact 132:21-30

Bowen R (1986) Groundwater, 2nd edn. New York, Elsevier

Brasil (2011) Ministry of Health. Ordinance No. 2914, 12/12/11. Disposes about procedures for control and monitoring of water quality for human consumption and its potability standards. Ministry of Health, Brasilia, pp 39-46
Brasil (1945) Mineral Waters Code - Decree Law No. 7841, de 08/08/45. DNPM - National Department of Mineral Production, Rio de Janeiro

Brasil (2005) Ordinance MS No. 518, 03/25/04. Ministry of Health, Brasilia

Campos JEG, Almeida L (2012) Thermal balance applied to artificial recharge of aquifers in Caldas Novas region, Goiás State. Braz J Geo 42:196-207

Campos EC, Costa JFG, Marques JMM (1980) Hydrogeological study project in Caldas Novas region, Goiás. In: ABAS (Brazilian Association of Groundwaters) (ed) Proceedings from I Brazilian Congresso f Groundwaters. ABAS, Recife, pp 401-414

Campos JEG, Tröger U, Haesbaert FF (2009) Hot springs of Caldas Novas, Goiás: a notable occurrence of thermal waters with no association to magmatism. In: Winge M, Schobbenhaus C, Berbert-Born M, Queiroz ET, Campos DA, Souza CRG, Fernandes ACS (eds) Geological and paleontological sites in Brazil, vol 2. CPRM (Mineral Resources Research Company), Rio de Janeiro, pp 177-190

CETESB (Environmental Company of São Paulo State) (1978) Technical Norm L5.127. Sulfide determination in water: methylene blue method. CETESB,São Paulo, 10p

CETESB (Environmental Company of São Paulo State) (2014) Appendix D-Environmental and sanitation meaning of quality variables. CETESB, São Paulo

CETESB (Environmental Company of São Paulo State) (2016) Groundwaters. CETESB, São Paulo

Costa RA, Nishiyama L, Silva GA (2013) Zoning of areas susceptibles to underground water contamination in Caldas Novas, State of Goias, Brazil. Braz Geogr J Geosci Humanit Res Medium 4(1):213-232

Ferreira LET (2003) Evaluation of geothermal resources in Goiás State. ON (National Observatory), Rio de Janeiro, 160p

Haesbaert FF, Costa JFG (2000) Geology and hydrology of Caldas Novas region: adaptation to the decree 312 of the DNPM. Caldas Novas, $123 \mathrm{p}$

Jardim WF (2014) Measurement and interpretation of redox potential (Eh) values in environmental matrices. J Quím Nova 37(7):1233-1235

Lazzerini FT, Bonotto DM (2014) Silicon in groundwaters of Brazil. Ciência e Natura 36(2):159-168

Mason B (1966) Principles of Geochemistry, 3rd edn. Wiley, New York

Peixoto Filho S (2000) Management contribution to the Caldas Novas/ Rio Quente Thermal Aquifer. MS Dissertation, Pernambuco Federal University, Recife, $183 \mathrm{pp}$

Silva LJHDER, Vasconcelos MAR, Silva DVG (2008) Timing and role of the Maranhão River Thrust in the evolution of the neoproterozoic Brasília Belt and Tocantins Province, central Brazil. Gondwana Res 13:352-374

Teixeira Neto A, Costa JEAM, Moura JU, Almeida OFR, Bucci RLF, Casseti V (1986) Caldas Novas Thermal Complex, v. 7. Goiás Federal University, Goiânia

Tonetto EM, Bonotto DM (1999) Implementação de metodologia para a análise química de águas e sua aplicação na caracterização das águas subterrâneas de Águas da Prata (SP). Geociências 18(2):303-325

Zobell CE (1946) Studies on redox potential of marine sediments. AAPG Bull 30:477-509 